\title{
野外環境教育プログラムにおける事後の復習教材開発 に関する研究
}

\section{A Study on the Technical Development of Review Materials for Field-Based Environmental Education}

斎藤 馨* 山本 祥子*

Kaoru SAITO Shoko YAMAMOTO

\begin{abstract}
The purpose of this study is to develop course review materials for use after activities in activity-based outdoor environmental education programs. Using all 10 lessons of the Chichibu supporter training course of the 2006 Tokyo University Forest as examples, along with every outdoor training program, the participants who take the course were asked to answer a questionnaire. Based on the results of the questionnaire, course review materials were developed, distributed to the participants after the activities, and finally, a repeated assessment questionnaire survey was performed for the course review material. Analysis of the results of the questionnaires revealed the following 4 points: (1) Elements and structure of course review materials for outdoor environmental education programs. (2) Incidental events that occur outdoors, but are unrelated to the educational content, may leave an impression on the students and are an important subject for the course review material. (3) Items evaluated as content of the course review material were divided into two categories "acknowledgement of the experience" and "new discoveries after the experience." (4) The course-review material developed enhances learning effectiveness after completion of the program, and at the same time, sustains enthusiasm for learning among absentees and encourages the desire to participate in the next lesson.
\end{abstract}

Keywords: natural environment, outdoor education, environmental education, environmental learning, review material キーワード : 自然環境, 野外教育, 環境教育, 環境学習, 復習教材

\section{1. 背景と目的}

環境基本計画 ${ }^{11}$ 第 3 部第 1 章第 7 節「環境教育・環境学習推進」 中の項目「多面的な学習による問題可決能力の育成」には, 『「体 験を通じて, 自ら考え, 調へ，学び, 行動する」という過程を重 視した学習を推進します。』と記されているように,「体験」は環 境教育・環境学習に必要な一つの手法である。環境教育そのもの は多種多様で, 例えば自然体験学習では, 自然に関する知識を教 えることよりも自然を体験し自然に対する感性を養うことに重点 が扔かれ，また野外教育活動では野外活動それ自体を教材とする 教育であるとされている ${ }^{2)}$ 。野外での環境教育では，知識よりも 自然体験の比重が高く, 野外での活動そのものが教材なのである。 一方, 自然体験学習に打ける学習内容・方法論の課題として, 「体験」がその場だけのものに終わってしまい，体験から帰って からの学習や行動に繋がらないとの指摘がある ${ }^{3)}$ 。つまり「体験」 の事後の「考え, 調へ, 学び, 行動する」過程への連続性の確保 が問題とされている。

森林を対象とした野外環境教育プログラムにおいて, 体験学習 の場となる森林内では，プログラムが予定していた事象に加えて 予定外の事象にも遭遇する。予定外の事象について, 講師が偶然 の機会を使ってその事象を説明したり, 受講者からの質問によっ て説明が行われたりすることがある。また説明に至らない事象で あっても, 受講者個人が印象深く記憶することもある。体験自体 が教材であるならば，実際の体験という教材には，体験プログラ ムの内容として予定されたものと, 予定外のものとが混じり合っ て存在するので, その体験から事後の学習へと繋ぐには,「体験」 に含まれる予定外の内容も含む教材が必要になるはずである。

そこで本研究の目的は次の 2 点である。(1)体験を基本とした野 外環境教育プログラムにおいて, 体験後に必要とされる復習教材 を検討し, 実際に作成すること。(2)作成した復習教材を評価分析 し，必要な内容と効果を明らかにすること。

\section{2. 対象亡方法}

研究は, 実際に行われている野外環境教育プログラムを事例と して取り上げ，体験学習後の復習教材を試作配布し，受講生から の評価を得ることで進めた。

(1) 対象

(i ）環境教育プログラム事例

東京大学秩父演習林サポー夕養成講座（以下「養成講座」之記 す) を本研究の調查対象事例とし，2006 年度新規の養成講座受 講生 16 名に 1 年間の調查協力を依頼した。養成講座は, 秩父演 習林で行われる一般市民向けの公開講座や一般公開などにおいて, 演習林スタッフを補助する役割を担うボランティアを養成するた めに実施されている体験プログラムである。

選定理由は, 以下の 2 点である。(1)受講生はサポー夕活動を行 うための基礎的な知識を身につける必要があり, 体験から調べ学 び，将来はサポータとして行動するための多面的な学習が想定さ

表 -12006 年度養成講座全 10 回タイトルと開催日および調査実施状況

\begin{tabular}{|c|c|c|c|c|c|c|}
\hline \multirow[b]{2}{*}{ 略称 } & \multirow[b]{2}{*}{ 講座タイトル } & \multirow{2}{*}{$\begin{array}{l}\text { 開催 } \\
\text { 月日 }\end{array}$} & \multicolumn{2}{|c|}{ 養成講座当日 } & \multicolumn{2}{|c|}{ 復習教材 } \\
\hline & & & \begin{tabular}{|l|} 
参与 \\
観察
\end{tabular} & \begin{tabular}{|l|} 
直後ア \\
ンケート
\end{tabular} & 作成 & $\begin{array}{c}\text { アンケー } \\
\text { ト }\end{array}$ \\
\hline $\mathrm{P} 1$ & 秩父演習林の教育研究 & $4 / 9$ & $\mathrm{O}$ & $x$ & $\times$ & $x$ \\
\hline P2 & 秩父演習林と秩父地方の歷史 & $5 / 16$ & $\mathrm{O}$ & $\mathrm{O}$ & $\mathrm{O}$ & $\mathrm{O}$ \\
\hline P3 & 秩父演習林の植物（樹木・草本） & $6 / 11$ & $*$ & $\mathrm{O}$ & $\mathrm{O}$ & 0 \\
\hline $\mathrm{P} 4$ & 秩父演習林の動物（哺乳類・昆虫） & $7 / 11$ & $\mathrm{O}$ & $\mathrm{O}$ & $\mathrm{O}$ & $\mathrm{O}$ \\
\hline P5 & 森林生態系の管理と利用 & $8 / 27$ & * & $\bigcirc$ & 0 & $\mathrm{O}$ \\
\hline P6 & 林業生産と育林技術 & $9 / 12$ & $\mathrm{O}$ & $\bigcirc$ & $\mathrm{O}$ & $\mathrm{O}$ \\
\hline $\mathrm{P} 7$ & \begin{tabular}{|l|} 
森林の公益的機能（水源涵養・防维） \\
\end{tabular} & $10 / 17$ & $\mathrm{O}$ & O & 0 & O \\
\hline P8 & $\begin{array}{l}\text { 秩父演習林（森林・施設）の管理・ } \\
\text { 運営 }\end{array}$ & $11 / 14$ & O & $\mathrm{O}$ & $\bigcirc$ & $\mathrm{O}$ \\
\hline P9 & 森林におりる安全管理 & $6 / 24$ & $\mathrm{O}$ & $\mathrm{O}$ & $\mathrm{O}$ & $\mathrm{O}$ \\
\hline P10 & 森林環境教育 & $11 / 18$ & $\mathrm{O}$ & $\mathrm{O}$ & $\mathrm{O}$ & (1) \\
\hline
\end{tabular}

○: 実施 $\times$ : 実施せず $*$ : 同行できず直後アンケートは演習林職員が代行

*東京大学大学院新領域創成科学研究科 
れる。その際に体験後の復習教材の需要があると考えた。(2後述 するが年間 10 日間 10 科目が開催されるため, 教材の試験開発と 評価を同一受講生を対象にして短期間に繰り返すことで, 復習教 材に関する知見を繰り返し確かめることが可能であること。

\section{(ii ) 養成講座の概要}

養成講座は, 2002 年度より毎年開催されている。年度ごとに 最大 20 名の受講生を登録し, 1 年間で 1 講座 1 日全 10 講座を開 講している。10 講座を 3 年以内で受講すると「秩父演習林サポー夕」 として登録されて活動ができる。1 講座は, 講座テキストによる座 学と現地実習で構成され, 2006 年度の養成講座タイトル, 開催日 は表－1の通りである。以後 P 1 P 10 は, 表一 1 の略称とする。

$\mathrm{P} 1$ 参与観察より，1 日の体験プログラムの時間割は，テキス トによる座学 1 時間 (AM 9:00-10:00), その後野外実習 (AM 10:00-PM 4:30）であった。野外実習はテキスト関連の内容と, テキスト外だが現場状況に合わせて予定した内容について, 見学 之説明が行われていた。この他, 現地や移動時に偶然に出会う事 象（動植物や, 現場作業, 天候や景観の変化など）について急遽 説明をしたり, また受講者がそれらを興味深く受け止める場合が

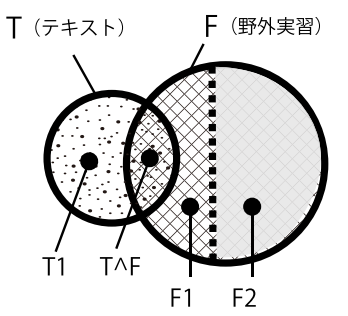

$\mathrm{T}$ 1： $\mathrm{T}$ から $\mathrm{T}^{\wedge} \mathrm{F}$ を除いた部分で，テキ ストだけの内容

$\mathrm{T}^{\wedge} \mathrm{F}$ : テキストと野外実習の両方で重複 する内容

$\mathrm{F} 1: \mathrm{F}$ から $\mathrm{F}^{\wedge} \mathrm{T}$ と $\mathrm{F} 2$ を除いた部分で, 養成講座において野外実習で教える内容 F 2: F のうち養成講座に予定されず, 野外で偶然に出会った事象について教え たり学んだりする内容。

図ー 1 養成講座におけるテキストと野外実習の関係

表一 2 養成講座テキストと野外実習, 直後アンケートの分類項目と内容

\begin{tabular}{|c|c|c|}
\hline $\begin{array}{l}\text { 分類 } \\
\text { 項目 }\end{array}$ & $\begin{array}{c}\text { テキスト記載内容、野外実習内容（テ } \\
\text { キスト内、テキスト外） }\end{array}$ & 直後アンケート \\
\hline 自然 & $\begin{array}{l}\text { 自然環境についての記述。ただし、奥秩父 } \\
\text { 特有の様子について書かれたものに限る }\end{array}$ & $\begin{array}{l}\text { 山、樹木、景色やその様子など自 } \\
\text { 然環境について書かれている }\end{array}$ \\
\hline 文化 & $\begin{array}{l}\text { 秩父地方の歴史や名跡、人工建造物などの } \\
\text { 文化に関わる記述 }\end{array}$ & $\begin{array}{l}\text { 人工建造物や、歴史などに関わる } \\
\text { ことについて書かれている }\end{array}$ \\
\hline 体験 & 奥秩父での実際の体験談が書かれている & $\begin{array}{l}\text { 〜したことっと書かれている。「都 } \\
\text { 会とは違う」なと受講者の非日常 } \\
\text { 的な体験と取れる内嫆 }\end{array}$ \\
\hline 学習 & $\begin{array}{l}\text { より専門的で学問的な内容。または奥秩父 } \\
\text { 特有ではなく、籍などにまとめ } \\
\text { られている内容 }\end{array}$ & $\begin{array}{l}\text { 地域性によらず、普過的なもので, } \\
\text { 教科書や専門書などにより習得が } \\
\text { 可能な知識 }\end{array}$ \\
\hline 人 & コミュニケーションに関わる記述 & $\begin{array}{l}\text { 受講者、スタッフなど人とのコ } \\
\text { ミュニーションに関わる内容 }\end{array}$ \\
\hline 環境 & $\begin{array}{l}\text { 環境保全や環境問題の意識に関係してい } \\
\text { るもの }\end{array}$ & \begin{tabular}{|l} 
環境保全や環境問題の意識に関係 \\
しいるもの \\
\end{tabular} \\
\hline その他 & 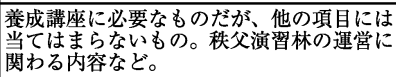 & $\begin{array}{l}\text { テキストのその他に分類したもの } \\
\text { に準ずる }\end{array}$ \\
\hline
\end{tabular}

2006.5 .16 サポーター養成講座ブログラム2「秩父演習林と秩父地方の歴史」

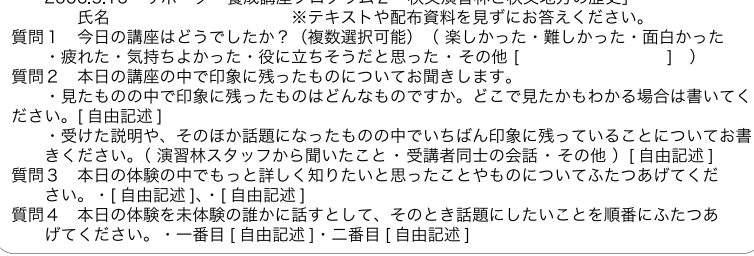

図一２＼cjkstart養成講座直後アンケート項目例（P 2)

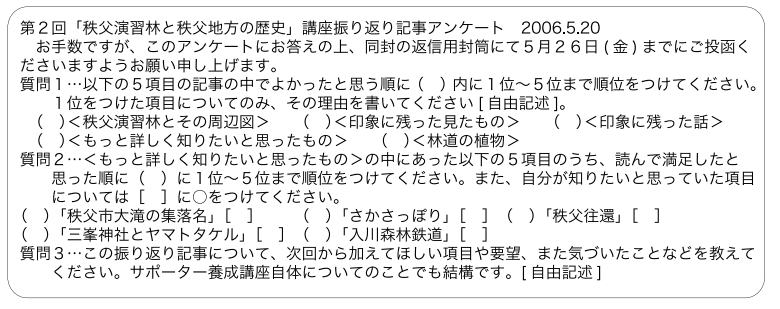

図一 3 復習教材評価アンケート項目例（P 3)

あった。これらの内容を整理すると図ー 1 のようになり，特に F 2 に関した教育や学習内容が存在することが特徴的であった。

\section{(2)方法}

以下の手順と内容で研究を進めた。

(i ) 養成講座の把握 : 養成講座について講座スケジュールとテ キストを入手した。

（ii）教育内容と野外実習後の復習教材の定義：テキストの内容 を分類するために表 -2 に示す 7 項目を作成した。テキストの 1 段落を最小カウント単位とし, 段落毎に表 2 の項目により分類し てカウントした。野外実習での説明内容は, テキスト内（テキス トに記載があり，野外でも説明した内容を指す）とテキスト外 （テキストに記載はないが野外実習で事前に予定した説明内容） とに区別して，テキストと同じ方法で分類し，カウントした。

（iii）体験プログラム毎の体験学習直後アンケート：養成講座に 同行し当日の説明や受講生の様子を参与観察した。また終了直後に 「印象」, より「知りたい」, 自身の体験を他者に「伝えたい」内容 を問うた直後アンケート（図－2）を実施し回収した。直後アンケー 卜内容も表 - 2 の区分に分類しテキスト内外に分けてカウントした。 （iv）復習教材を製作と送付：直後アンケート結果と参与観察結 果を踏まえ復習教材を作成し, 復習教材評価アンケートとともに 講座当日から 3 日目に受講者に送付した。

( v ) 復習教材評価アンケートの実施と回収：評価アンケート （図－3）は, 復習教材の記事に関する評価を問うた。講座当日 より 10 日後をみ切り日として郵送返信により回収した。

（vi）講座毎の繰り返し実施：（iii）（iv）（v）について, 表一 1 に示すとおり 9 回実施した。

(vii) 養成講座と直後アンケートとの関係分析と教材試作指針把

表 -3 第 2, 3 回養成講座のテキスト, 現地実習, 直後アンケート分類集計結果

\begin{tabular}{|c|c|c|c|c|c|c|c|c|c|c|}
\hline & \multicolumn{3}{|c|}{ 養成薯座 } & \multicolumn{6}{|c|}{ 直後アンケート } \\
\hline & & 㭫学 & \multirow{2}{*}{\multicolumn{2}{|c|}{ 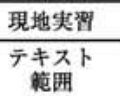 }} & \multicolumn{2}{|c|}{ 印象 } & \multicolumn{2}{|c|}{ 知りたい } & \multicolumn{2}{|c|}{ 伝えたい } \\
\hline & & \multirow{2}{*}{$\begin{array}{l}\text { テキ } \\
\text { スト }\end{array}$} & & & \multicolumn{6}{|c|}{ テキストとの関連性 } \\
\hline & & & 内 & 外 & 有 & 無 & 有 & $\begin{array}{l}\text { 無 } \\
\end{array}$ & 右 & 無 \\
\hline \multirow{8}{*}{ 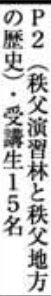 } & 自然' & 1 & 1 & $\overline{0}$ & 14 & $\overline{0}$ & $\overline{4}$ & $\overline{0}$ & 3 & $\overline{2}$ \\
\hline & 文化 & 61 & 24 & 2 & 11 & 1 & 14 & 0 & 15 & 3 \\
\hline & 体涘 & 0 & 0 & 0 & 2 & 1 & 1 & 1 & 2 & 2 \\
\hline & 学習 & 0 & 0 & 4 & 2 & 3 & 0 & 8 & 0 & 2 \\
\hline & 人 & 0 & 0 & 1 & 5 & 1 & 0 & 0 & 0 & 0 \\
\hline & 環境 & 2 & 1 & 0 & 2 & 0 & 0 & 0 & 0 & 0 \\
\hline & その他 & 3 & 0 & 0 & 0 & 0 & 0 & 0 & 0 & 1 \\
\hline & 领 & 67 & 26 & 7 & 36 & 6 & 19 & 9 & 20 & 10 \\
\hline \multirow{7}{*}{ 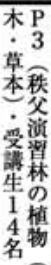 } & 自然 & 8 & 7 & $\overline{0}$ & 17 & 0 & 6 & 0 & 10 & $\overline{0}$ \\
\hline & 文化 & 0 & 0 & 1 & 0 & 0 & 0 & 2 & 2 & 2 \\
\hline & 体涘 & 0 & 0 & 0 & 3 & 0 & 1 & 0 & 0 & 0 \\
\hline & 学習 & 100 & 47 & 0 & 14 & 0 & 11 & 1 & 11 & 1 \\
\hline & 人 & 0 & 0 & 0 & 2 & 0 & 0 & 0 & 2 & 0 \\
\hline & 環境 & 0 & 0 & 0 & 0 & 0 & 0 & 0 & 0 & 0 \\
\hline & その他 & 0 & 0 & 0 & 0 & 0 & 0 & 0 & 0 & 0 \\
\hline 楖 & 部 & 108 & 54 & 1 & 36 & $\overline{0}$ & 18 & 3 & 25 & $\overline{3}$ \\
\hline
\end{tabular}

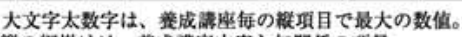

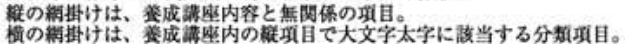

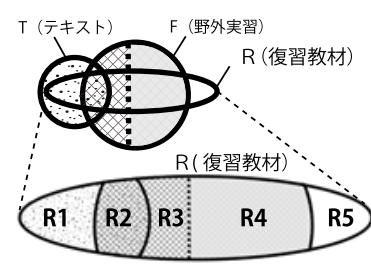

図- 4 養成講座と復習教材との関係
$\mathrm{R} 1 ： \mathrm{~T} 1 \wedge \mathrm{S}$ の部分で，復習教材に含まれ るテキストのみで学習する内容 $\mathrm{R} 2: \mathrm{T} \wedge \mathrm{F} \wedge \mathrm{S}$ の部分で，復習教材に含ま れるテキストとフィールドの両方で重複し て学習する内容

R 3 : F $1 \wedge$ S の部分で, 復習教材に含まれ る養成講座の学習内容として野外実習で 体験学習する内容

$\mathrm{R} 4: \mathrm{F} 2 \wedge \mathrm{S}$ の部分で, 復習教材に含まれ る野外実習で偶然受講者が学ぶ内容 R 5 : 復習教材に新規に加える知識や情報 
握：養成講座と直後アンケートについて，その内容分類を付き合 わせて体験プログラムが想定する教育内容と, 養成講座当日の野 外実習後の受講者の要望や印象に対応させた評価分析を行ない, 教材作成の指針を得た。

（viii）復習教材の開発と評価：（v）で回収したアンケートにより 個々の復習教材の評価分析を行った。また最終回 P 10 では総ま とめアンケートを実施し，復習教材全般についての評価を分析した。

\section{3. 結果と考察}

\section{(1) 養成講座}

養成講座についてはその概要を2（）に）記した。

\section{（2）養成講座と直後アンケート}

養成講座のテキスト, 現地実習, 直後アンケートの分類集計に ついて，P 2 と P 3 についての結果を表一 2 に示した。

( i ) P 2 について太字数字に着目する。歴史文化に関わる講座 なので，テキストやテキストに関連した現地実習において「文化」 に関する項目数が多く, 受講生への直後アンケートの回答内容も, 「知りたい」「伝えたい」で講座関連内容が最大となっている。一 般的な知識に関する「学習」では, 現地実習でテキスト外である が 4 項に触れたためか, 直後アンケートの「印象」「知りたい」 でのテキスト無関係項目が最大となっている。「印象」では,「自 然」が最大であり,「知りたい」の内容では, 『樹木や草本の名前 を知りたい』と回答した受講者が 15 名中 13 名であった。P 2 の 開催日は 5 月なので, 野外実習では新緑や草花を目にすることが 多いことが影響したと考えられる。

(ii） P 3 について, 太字数字に着目する。植物に関する講座で, テキストは一般的で学問的な植物に関する内容である。「学習」 が多く, 現地実習でもテキストと関連した「学習」が多い。これ と関係して直後アンケートの「知りたい」「伝えたい」のテキス 卜関連内容が最大となっている。「印象」については, 野外で目 にする自然に関連する項目に集中している。現地実習でテキスト 外で「文化」に触れているため,「知りたい」「伝えたい」でのテ
キスト無関係での回答が多い。

（iii）直後アンケートのまとめ

（i ），(ii）の分析はさらにP 4 10 まで同様に行った。集計表は 紙面の都合で割愛するが，傾向を取りまとめると以下のようになる。 養成講座では, 教える側が準備するテキストや座学での説明, 野外実習での説明など事前に準備された教育内容が，受講者のよ り「知りたい」，他者に「伝えたい」ことに直接影響を及ぼす。一 方で野外での「印象」については，当日の講座の内容だけでなく， 野外での偶然の体験に印象づけられることがある。野外での偶発 的な体験は印象に残るが，これは野外での体験学習の特質でもあ るので，これを復習資料に反映させることは意義があると考えた。

\section{(3) 養成講座復習教材の開発と評価}

（i ）養成講座と事後教材の関係：前節での直後アンケートを元 に, 受講生が養成講座後に, 講座内容の確認や, 気づきを発展的 に学習するための復習教材に必要な内容を, 養成講座との関係か ら検討した。養成講座が教える内容の復習を基本とし, 当日の偶 発的事象を含む体験が印象と残ることから，気づいた内容をより 深く発展させながらも，印象とともに学習内容を復習できる教材 が理想である。つまり図 1 中の T 1, T^F, F 1, F 2 のそれぞれに 関連した内容が基本となる。さらに養成講座では触れられなかっ た新たな知識や情報も 加えることを考え，開 発する復習教材の内容 図一 1 を元に検討した 結果が図ー4である。 復習教材の内容を, 図 中の R 1 R 5 に区分 した。養成講座で事前 に準備した教えるべき 内容に関する復習内容 が R 1 R 3, さらに野 外実習での偶発的に遭
表 -4 復習教材の紙面構成

\begin{tabular}{|c|c|c|c|}
\hline $\begin{array}{l}\text { 頑 } \\
\text { 号 } \\
\end{array}$ & 記事種類 & 内容 & $\begin{array}{c}\text { 関連分類 } \\
\text { 記号 } \\
\text { (図 } 4 \text { 参照) }\end{array}$ \\
\hline 1 & $\begin{array}{l}\text { 養成講座 } \\
\text { 行程復習 }\end{array}$ & $\begin{array}{l}\text { 当日の順路、時間構成、 } \\
\text { 気なと概要 }\end{array}$ & $\mathrm{R} 2, \mathrm{R} 3, \mathrm{R} 4$ \\
\hline 2 & 復習 1 & $\begin{array}{l}\text { 直後アンケート「印象」 } \\
\text { 結果と関連情報 }\end{array}$ & $\begin{array}{l}\text { R1, R2, R3, } \\
\text { R4 }\end{array}$ \\
\hline & 復習 2 & \begin{tabular}{|l} 
直後アンケート「知りた \\
い」結果と関連情報 \\
\end{tabular} & $\begin{array}{l}\mathrm{R} 1, \mathrm{R} 2, \mathrm{R} 3, \\
\mathrm{R} 4\end{array}$ \\
\hline \multirow[t]{2}{*}{3} & その他 & $\begin{array}{l}\text { 養成講座内容と無関係だ } \\
\text { が当日話題になった事項 }\end{array}$ & $\mathrm{R} 4$, 例外 * \\
\hline & & $\begin{array}{l}\text { 養成講座と関連性のある } \\
\text { 规容 }\end{array}$ & R5 \\
\hline
\end{tabular}

No.1（1 枚目）

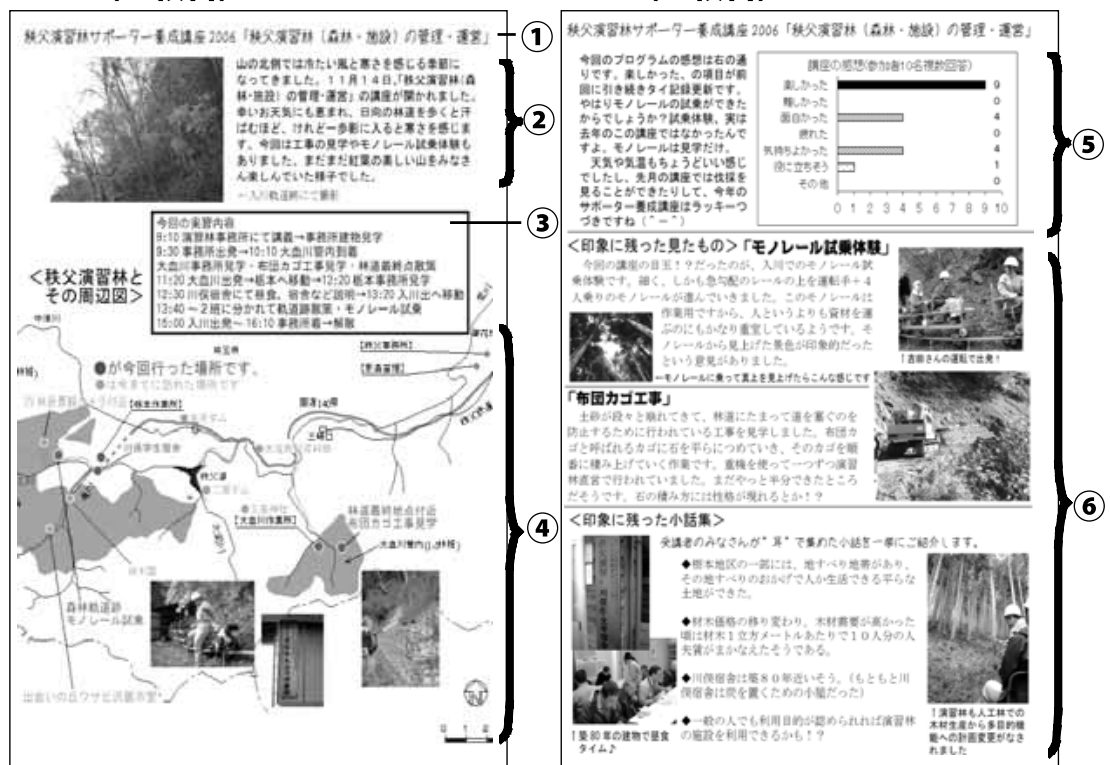

\section{No.3（3 枚目）}

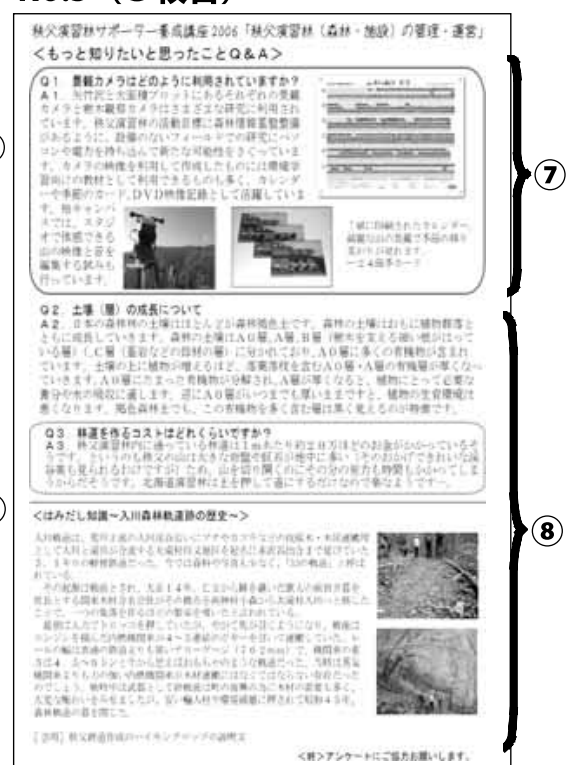

(1)表題：講座のタイトル名 (2)はじめに：講座当日の現地フィールドの天候と主な学習内容や受講者の㥞子などを写真とともに記載（3)実習内容：講座当日の内容を，時 間を追って移動場所とともに記載 (4)秩父演習林とその周辺図：秩父演習林事務所から演習林内を含む地図を揭載し，当日訪れた場所をポイントして，そこで撮影した写 真とともに紹介。1 度訪れた場所は，色違いでそのままポイントされている。(5)講座の感想：直後アンケートでの受講者の 1 日の感想をグラフ化。その他の意見があっ

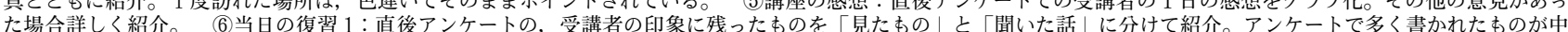

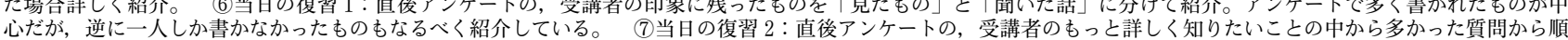

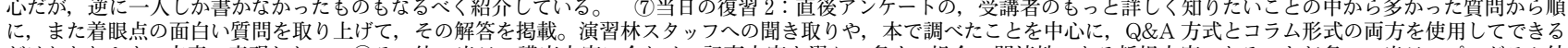
だけわかりやすい文章で表現した。(8)えの他：当日の講座内容に合わせて記事内容を選ぶ。多くの場合, 関連性のある新規内容であることが多い。当日のプログラム外 での印象的な出来事を掲載するときもある。(6)，7の記事量によって掲載量や記事の内容を調整するため割愛されるときもあった。

図- 5 復習教材例（第 8 回養成講座「秩父演習林(森林・施設）の管理・運営」）と構成内容 
遇した内容に関しては R 4 により復習する。そして講座では取り上 げられないが, 偶発的で貴重な体験に関する内容で講座と関連する 新しい内容を R 5 とした。

(ii) 復習教材の構成：復習教材は郵送とするため紙メディアと し, 養成講座を簡潔に復習するための試作教材なので紙面量は最 小限と考え A 4 用紙 3 枚とした。紙面構成は表一 4 に示すよう に, 記事の種類を当日の行程を振り返る「養成講座行程復習」, 直後アンケートの「印象」に関連した「復習 $1 」$, 同じく「知り たい」に関連した「復習 $2 」$ ，そして新規内容を含む「その他」 で構成することにした。

（iii）復習教材と評価：復習教材は P 2 P 10 の 9 回作成したが, 図 5 にP 8 の復習教材例とそれぞれの構成内容の意図を記した。 毎回復習教材送付時に評価アンケートを行ったが，図ー 3 中の問 1 で 1 位を記録した記事について，A.養成講座行程，B.復習，C. 質問回答，D.新規内容の 4 つに分けた集計結果を表一 5 に示す。 9 回の合計值より, 復習記事が最も評価が高く, 次いで質問への 回答, そして新規内容となった。また, 自由回答による復習教材 に対する評価は以下の 2 つまよめることが出来た。

a.確認：「体験したことを振り返ることが出来る」,「知識の復 習（整理・確認）に役立つ」，「思い出として残る」

b.新発見：「他の参加者の感想や体験を共有できる」，「新しく 知ることで更に考えるきっかけになる。」自分の居ないところで の説明や聞き漏らしていたことが分かる」

これにより, 受講者は, 復習教材により養成講座についての 「確認」と「新発見」を行っていることが分かる。

（iv）養成講座欠席者への復習教材評価 : 復習教材を 4 回 (P 2,P 3,P 3,P 9) 発送した養成講座前半終了時に, 復習教材の送付 希望についてアンケートを実施したら, 久席日の復習教材の送付 を希望する受講生は 14 人中 12 人であった。その後の P $5,6,7,8$ について欠席者に復習教材を送 付し，欠席日の復習教材に関す るアンケートを行った結果を表一 6 に示した。これより欠席時の 講座の内容を理解できるほか, 次回への参加意欲を高めること が分かった。また「読んでもよく 分からない (1 名)」の意見では 「文章だけで写真がないと分から ない」とあり，野外実習での記 録に写真の重要性が示唆された。

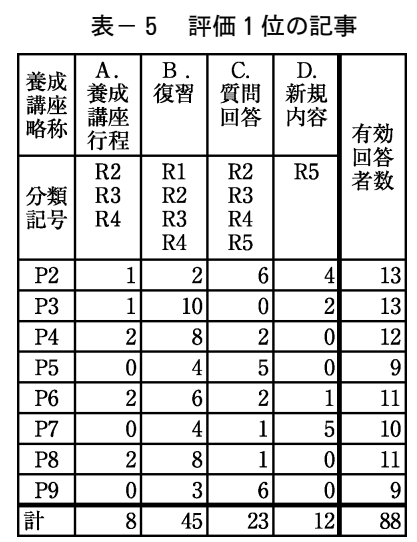

表－6 養成講座欠席者が復習教材を読んで感じたこと $(P 5,6,7,8)$

\begin{tabular}{|c|l|r|}
\hline 記号 & \multicolumn{1}{|c|}{ 質問内容 } & 回答数* \\
\hline ア & 当日欠席したが、講座の内容がよく分かった & 10 \\
\hline オ & 次回の講座には出来るだけ参加しようと思った & 8 \\
\hline ウ & 当日欠席したが、読み物ととして利用できるので良い & 5 \\
\hline エ & 当日欠席したので、読んでもよく分からない & 1 \\
\hline$イ$ & 当日欠席したので、振り返り記事はあまり意味がない & 0 \\
\hline
\end{tabular}

*回答者 12 名複数選択可

表 -7 総まとめアンケート集計[講座に参加したときの復習教材の利点」

\begin{tabular}{|c|c|c|}
\hline 記号 & 質問内容 & 回答数 ${ }^{*}$ \\
\hline イ & $\begin{array}{l}\text { 他の参加者がその日の学習と体験でどう感じたか、知ることが } \\
\text { できる }\end{array}$ & 10 \\
\hline オ & $\begin{array}{l}\text { 質問の回答や整理された内容が載っていることで、より理解や } \\
\text { 浬かる }\end{array}$ & 10 \\
\hline 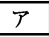 & その日 1 日限りの学習と体験を絽り返し思い出しやすい & 7 \\
\hline 力 & その他 & 6 \\
\hline ウ & 参加した思い出として取っておくことができる & 3 \\
\hline I & 参加した日からあまり間をおかないで自宅に記事が届く & 2 \\
\hline
\end{tabular}

*回答者 12 名複数選択可 （v）年間を通じての復習教材の評価： 1 年間の養成講座の最後 に総まとめアンケートを行った（表－1）。紙面の都合上，アン ケート項目は省略するが，全受講者 16 名中 12 名から回答を得た。 表 7 に復習教材の必要性と利点について結果を示した。

a.養成講座に復習教材の必要性については, 11 名が必要と回 答し，不必要は 0 , 必要だが形式は変更すべきが 1 名であった。

b.復習教材の利点にいて複数回答での問については, 結果を表一 7 に示す。前節(iii)で示したと同様に，「新発見」であるイ，「確 認」であるオ，アが選択数が多い。力（その他）では, 『体験を 記録に残せる』の「確認」と，『講座全体を他者の目を通して見 ることが出来る』『見落としをカバーできる』などの「新発見」 とに大別できた。

\section{4. おわりに}

本研究では, 野外体験による環境教育プログラムにおいて, 体 験後の復習教材の開発を行った。実際の体験プログラムに同行し， 受講者へのアンケートを元に復習教材を試作，配布し，評価を繰り 返し開発しながら，復習教材に関する知見を得た。受講生 16 名に 9 回にわたり提供した復習教材は概ね好評であった。復習教材の 内容には，「確認：体験プログラムに沿った復習と関連する発展 事項に関する記事」と「新発見：野外体験で偶発的に経験し印象 に残った事項についての新たな知識に関する記事」に大別された。

体験プログラムはともすると現場体験に終始し，教育内容が不 明確になったり, 野外から帰って来た後は, 日がたつにつれ習得 した知識や貴重な体験が忘れ去られ思い出だけが残り, 復習など がおろそかになりがちであるが，復習教材はこうした体験プログ ラムの問題点への対策として有効であった。しかし復習教材で扱 えることは，環境基本計画が言う「調へ，学び，行動する」のう ちの「調べ，学び」であって，「行動する」に関してはまた別な 方法が検討されるべきであろう。

一方，今回の一連の復習教材開発では，野外体験に同行し，受 講者の様子や現場での出来事を把握して復習教材を作成したので, その場に居合わせたからこそできる些細なフォローアップ記事, つまりその場限りの事象に関する記事が特徵的であった。体験プロ グラムには，プログラムに同行し，野外での受講者や現場状況を記 録して，それらを復習教材の一部に当てる努力が必要である。野外 での環境教育活動は，いわば二度と同じことがない生きた講義なの で，その都度振り帰りのための取材と受講者へのフィードバックが必 要であり，これはプログラムに事前に組み込むべきであり，教える側 の作業努力が必要となる。今後は体験プログラムにおいて復習教材 を作成に必要な野外体験記録方法について研究を深めたい。

謝辞 : 本研究の遂行につきまして東京大学大学院農学生命科学附 属秩父演習林のご協力頂きました。また同演習林 2006 年度サポー 夕一養成講座受講生の皆様には, 現地養成講座や試作教材につい て何度にも及ぶアンケートにご協力いただきました。お陰様で貴 重なデー夕を収集でき，研究を取りまとめることが出来ました。 ここに記して感謝の意を表します。

\section{参考文献および補注}

1 ）環境省企画調整局編(1994）：環境基本計画：大蔵省印刷局, P 66

2 ) 佐島群巳・鈴木善次・木谷要治・木俣美樹男 - 小島紀美子 ・ 高橋明子編（1996）：環境教育指導辞典：国土社，p.266, 276

3 ) 降旗信一(2005)：「自然体験学習実践における青少年教育の 現状と課題：自然学校の成立と発展に注目して」：ESD 環 境史研究：持続可能な開発のための教育 : 東京農工大学, 4 (20050900), 32-40 